\title{
A Semântica, a Intenção e o verbo planejar
}

\author{
Arturo Délano de La Cruz (C. D.; M.S.P.)*
}

Este texto reflete só os critérios do autor e não da instituição em que ele trabalha - Apresentam-se situações inclusive anedóticas para contribuir a determinar o que é, ou pode ser a ação de planejar - programar em Saúde.

Aceita-se hoje em alguns meios intelectuais, que os Planos em geral são exercicios estratégicos dos politicos, já que eles incorporam sempre a ideologia na sua aspiração legítima e crônica da tomada do poder. - Acrescenta-se que as mudanças no setor Saúde só poderiam ser propostas por quem exerce ou negocia o poder (correlação de forças) ou por círculos periféricos próximos dele. - A partir daí, então, constroem-se algumas considerações epistemológicas sobre o ingênuo e o cândido que é discutir como racionalizar os recursos e/ou propor estratégias técnicoadministrativas para programar ações que fomentem, previnam e recuperem a Saude de nossas comunidade doentes.

Quando o setor Saúde gera propostas metodológicas de como prever por antecipação sittıiçôes, os intelectuais comentam que a visão micro do problema, geralmente biológico, não permite que as variáveis sociais macro sejam analisadas e incorporadas no processo de formulação e execução das atividades operacionais.

$\mathrm{Li}$, há poucas semanas, um documento no qual se afirmava que. . "os enfoques normativos em planejamento de Saúde foram utilizados perversamente pelos governos autoritários, obedecendo à lógica de desacreditar, diante da sociedade, as organizações públicas responsáveis pela assistência médica, como uma maneira de fortalecer o projeto privatizante - conservador".

Rconheço a minha incapacidade para processar uma tese como a citada anteriormente porque existem experiências vividas, ontem e hoje, que utilizam normas programáticas para organizar e definir melhor o trabalho e a responsabilidade das estruturas existentes no setor.

O que se coloca, então, como proposta operacional adequada para definir o trabalho dos profissionais da SAÜ$\mathrm{DE}$ ? E como definir desde o governo ou desde a oposição o que deve ser, ou, o que pode ser? Esperar a tomada do poder para uma proposta macro que totalize a solução social?

Um professor da ENSP expressava diante de um auditório de alunos e docentes que ele achava que "(SIC)... enCadernos de Saúde Pública, R.J., 2(4): 243-245, abr/jun, 1988.
Odontologia Social ENSP-Fiocruz 
quanto o povo doente sofria, os intelectuais se divertiam discutindo hipóteses que demoram dramaticamente a abordagem técnica para diminuir ou eliminar morbidades e mortes evitáveis"(1).

Aos que perguntamos, por exemplo: como se instrumentalizam as propostas da Comissão Nacional da Reforma Sanitária (C.N.R.S.) em um país que privilegia a política econômica de mercado (monetarismo), em que tudo se compra ou se vende? Respondeu-nos habitualmente que tudo depende da Constituinte, ou do Presidente da República, ou dos Ministros de Saúde, da Previdência, da Educação, e que potenciariam-se estas propostas pela mobilização social que se atingisse.

Outro professor da ENSP refletia acerca destas mobilizações sociais e dizia. . ." sobrevaloriza-se a capacidade real e de representação que as organizações sociais têm no Brasil. .. A seleção natural e a geração das lideranças consolidam-se por mecanismos alheios às ideologias. . . Estas lideranças mudam de posições constantemente, dificultando sua tipificação ou enquadramento. . . Não há referências lógicas para identificar a que setores representam"...

Acrescentava o professor". . . Nas reuniōes que se mantêm para integrar as ações de saúde na CIS de RJ aparecem e participam representantes da comunidade que ninguém identifica exatamente como tais. . . Dizem representar aos beneficiários potenciais, usuários dos serviços que se pretende estadualizar, unificar e integrar. . . Ao que parece, cada uma das instituiçôes comprometidas com este processo notifica e cita a grupos de pessoas que assumem por si a representação comunitária. . . se tem a sensação, então, de que o controle social e a democratização se exercem automaticamente por este fato. . . Tenho a percepção que nestes esforços racionalizadores da CIS do RJ se improvisa e não se planeja quem decide a direcionalidade operativa a ser seguida e do subsetor que fornece e dispõe do dinheiro institucional necessário"(2).

Cito estas reflexões sobre o problema conjuntural das variáveis políticas contingentes, porque são referências teóricas para adequar uma proposta medianamente aceitável que soma vontades e anseios que mudem positivamente a situação existente.

Há alguns anos atrás, discutimos no Chile, no nível central da Direção Geral de Saúde (Serviço Nacional de Saúde), a necessidade de modificar progressivamente o estilo de tomar decisões à medida que fosse sendo executado o "Plano Sexenal de Saúde do Governo Popular de Salvador Allende (1971-1976) - Reconhecíamos que a Planificação

(1) Szchana Elliaz Cynamon

(2) Adolfo Chorny
- Programação era uma ferramenta de trabalho da estrutura, e por isso, devia ser singela, eficaz e eficiente. Os níveis 
de atenção na frente da demanda deveriam ser os que decidissem qual enfoque adotar e melhor utilizar os recursos e decidir que atividades deveriam ser feitas - Os níveis regionais e o central deveriam apenas consolidar e distribuir os recursos necessârios para ir oferendo, paulatinamente, uma atenção de maior cobertura e de melhor qualidade.

Pensávamos que todos os esforços supra-estruturais deveriam estar dirigidos a fortalecer a relação serviço.paciente, isso seria a medida exata de nossa eficácia e eficiência. Agora bem, esta descentralização deveria ter sempre uma referência técnico-administrativa superior (hierarquização) para que cada serviço não se tornasse um entre absolutamente autônomo componente de um Sistema de Saúde Anárquico, que ninguém poderia controlar e avaliar.

Sempre seria necessário um consenso mínimo sobre as regras (normas) de como organizar melhor o trabalho, determinando as responsabilidades, as funçōes, os deveres e os direitos daqueles que prestam atenção e daqueles que a recebem, garantindo mecanismos de participação real dos atores do problema na etapa de formulação das políticas e dos programas. Alguém tem que iniciar a proposta racionalizadora do Plano Zero. Alguns sustentam que a agudização das contradições dos fatores que condicionam a Saúde per se gerariam espontaneamente mobilizações sociais que demandariam soluçōes às estruturas do governo. Outros acreditamos que esta acumulação de males endêmi$\cos$ produzidos pela injustiça social imperante não pode nem deve piorar mais e que nossa responsabilidade e conseqüência ideológica nos deve obrigar agora a agir com o conhecimento existente, sob pena de entrar numa espiral diabólica sem retorno, $o$ que poderia significar a eliminação de quaisquer vertígios de civilização humana.

Não há ironia neste parágrafo final. . . Solicito, humildemente, orientação, ajuda e discussão permanente para superar minhas preocupaçōes e inquietaçōes atuais. Tenho necessidade de me sentir útil e contribuindo numa equipe de trabalho multidisciplinar dedicado sinceramente a melhorar o nível de vida de nossas comunidades. rando"

"Al César lo que es del Cesar y a Dios que me voy llo-

(Folklore chileno) 